\title{
PLURALISME AGAMA MENURUT NURCHOLIS MADJID (1939-2005) DALAM KONTEKS KEINDONESIAAN
}

\author{
Catur Widiat Moko \\ Program Pascasarjana \\ Universitas Islam Negeri Raden Fatah Palembang \\ E-mail: Widiatmoko_uin@radenfatah.ac.id
}

\begin{abstract}
This research entitled "Religious Pluralism According to Nurcholish Madjid in Indonesian Context '. Based on the phenomenon that occurred in the field many Muslims who more emphasize the symbol of religion than the application in menjlankan religion so that underlie thinking Nurcholis Madjid in overcoming msalah.dilakukan three stages of work that is Inventory, Evaluation, and Synthesis. The writings that have been obtained will be reviewed, an analysis of the thoughts of Nurcholish Madjid. The research approach is historical approach, while in historical research using heuristic technique, verification, intervention, and historicistography. The results of this study can be summarized as follows, First, the basis of religious pluralism is that the universal religion of Islam encompasses all aspects of life, Pancasila is the foundation of the state of Indonesia so that we must do tolerance and compete in the good. Secondly, that the implications of religious pluralism recognize religious freedom, live with the risks that will be borne by each believer. The will of God is above the will of man in setting anything. Thirdly, the principle of religious pluralism is the open, dialogical, tolerant and upholding of human values which at the same time embodies a peaceful and open Islam.
\end{abstract}

Keywords: Pluralism, Religion, Nurcholis Madjid

\begin{abstract}
Abstrak
Penelitian ini berjudul "Pluralisme Agama Menurut Nurcholish Madjid dalam Kontek Keindonesiaan'. Berdasarkan Fenomena yang terjadi di lapangan banyak umat islam yang lebih menonjolkan symbol agama dari pada aplikasi dalam menjlankan agama tersebut sehingga mendasari pemikiran Nurcholis Madjid dalam mengatasi msalah tersebut.dilakukan tiga tahapan kerja yaitu Inventarisasi, Evaluasi, dan Sintesis. Karya-karya tulis yang sudah didapatkan akan dilakukan penelaahan, analisis mengenai pemikiran Nurcholish Madjid. Pendekatan penelitian yaitu pendekatan sejarah, adapun dalam penelitian sejarah menggunakan teknik heuristik, verifikasi, intervretasi, dan historisografi. Hasil penelitian ini dapat disimpulkan sebagai berikut, Pertama, dasar pluralisme agama adalah bahwa islam agama yang universal mencakup semua aspek kehidupan, pancasila merupakan dasar negara Indonesia sehingga yang harus kita lakukan toleransi dan berlomba-lomba dalam kebaikan. Kedua, bahwa implikasi dari pluralisme agama mengakui kebebasan beragama, hidup dengan resiko yang akan ditanggung oleh masing-masing pemeluk agama.Kehendak Tuhan di atas kehendak manusia dalam menetapakan apapun. Ketiga, prinsip dari pluralisme agama yaitu dakwah yang terbuka, dialogis, toleran dan menjunjung tinggi nilai-nilai kemanusiaan yang sekaligus mewujudkan Islam yang damai dan terbuka.
\end{abstract}

Kata kunci: Pluralisme, Agama, Nurcholis Madjid 
Bangsa Indonesia merupakan bangsa yang memiliki bermacam suku bangsa, budaya, bahasa, dan agama. Secara umum agama diartikan sebagai ajaran yang berasal dari Tuhan atau hasil renungan manusia, yang terkandung dalam kitab suci yang turun temurun diwariskan oleh satu generasi ke generasi selanjutnya. Bertujuan untuk memberi tuntunan dan pedoman hidup bagi manusia agar mencapai kebahagiaan di dunia dan akhirat. Agama sebagai the way of life mampu memberikan jawaban setiap persoalan-persoalan yang muncul dalam kehidupan. Jika agama dipahami dengan hakikat filsafat, akan memperkuat keyakinan beragama secara intelektual. Secara psikologis agama juga menjalankan suasana hati dengan memberikan motivasi secara kuat sehingga dapat memberikan keyakinan dan ketenangan kepada para pemeluknya. Bahkan, ketika agama dipahami secara sosiologis, para pemeluknya semakin bertoleransi antar agama dan inter agama (Kuntowijoyo, 2004: 123).

Agama dan masyarakat secara kesatuan mempunyai jalinan yang erat dan saling mempengaruhi satu sama lainnya. Dalam agama terkandung sumber nilai dan moral universal sehingga dapat membentuk sikap dan prilaku manusia dalam menjawab tantangan kehidupan. Bahkan dikatakan manusia sebagai makhluk sosial belum menjadi manusia sepenuhnya tanpa agama. Dalam sebuah dialog antara teolog bernama Leonardo Boff dan Dalai Lama menjelaskan bahwa "yang membuat seseorang menjadi baik, lebih sabar, peduli antar sesama, memiliki rasa kemanusiaan, bertanggung jawab, dan beretika, maka agamanya telah bekerja", dalam dialog mengajarkan bahwa betapa agama dapat menjadi amat fungsional dan bekerja dengan baik, ketika agama dapat merefleksi pada perilaku keseharian seseorang menjadi pribadi yang baik. Agama bukan nilai yang terpisah dari kehidupan nyata, tetapi menyatu dalam perilaku manusia.

Agama merupakan aturan hidup manusia yang memberikan pengajaran serta nilainilai kebaikan yang harus dikerjakan setiap pemeluknya. Adapun dalam bahasa Schimmel, yang dikutip dari Andito (Andito, 1998: 51), sebagai dimensi kohesi dan konsensus yaitu suatu hubungan yang membangun komunikasi dalam nilai-nilai hukum yang ada dalam kontruksi setiap agama, agama dapat ditafsirkan dalam peran ganda (Double Standard). Artinya, agama sebagai penyebab konflik sekaligus dapat menjadi faktor peredam konflik.

Faktor-faktor tersebut dapat dilihat pada tataran idealisasi informasi yang disampaikan para pemuka agama kepada jamaahnya. Dari sisi agama Islam mengajarkan kasih-sayang bagi seluruh alam (Rahmatan Lil Alami'in) (Madjid, 2004: 81) dalam agama Kristen dan Katolik mengajarkan cinta kasih dalam jalan Yesus dimana umat manusia adalah bersaudara (Diputra, 2004: 135), dalam agama Buddha mengajarkan tentang kesederhanaan dimana dunia merupakan tempat yang penuh derita, dalam agama Hindu mengajarkan kebijaksanaan, yang muncul kemudian membangun fenomena keberagaman sebagai kontsruksi teologis masingmasing pemeluk agama.

Konflik yang terjadi dapat dilihat sebagai bentuk sentrisme dalam memahami ajaran sebuah agama di tengah masyarakat yang multikultural. Wilayah kebenaran penafsiran agama sering menggunakan standar ganda, kebenaran dianggap menjadi otoritas kelompok agama sendiri, sedangkan umat beragama lain dianggap jauh dari kebenaran. Inilah yang dikatakan oleh Prasudi Suparlan (Zuly, 2003: 392), bahwa persaingan antar etnis tidak selalu menimbulkan konflik berdarah. Padahal ini dapat dicegah jika para anggota etnis-etnis tersebut mematuhi hukum yang berlaku dan tetap memelihara tatanan sosial. Tidak menutup 
kemungkinan bahwa konflik yang terjadi diakibatkan oleh adanya fanatisme berlebihan dalam memandang salah satu agama lebih baik dari agama yang lainnya. Agama lebih melibatkan aspek emosi dari pada rasio, lebih menegaskan "klaim kebenaran" daripada "mencari kebenaran".

Banyak agama dan kultur yang ada di Indonesia, dan kemudian menjadi konflik antar umat beragama, menunjukkan bahwa agama yang diharapkan membawa misi rahmat bagi seluruh umat, tidak lagi menunjukkan peranannya secara signifikan. Banyaknya agama dan etnis yang ada di Indonesia justru berdampak pada kesalahan pemahaman dan pemaknaan atas nilai-nilai kehidupan beragama. Hal ini kemungkinan besar disebabkan karena paham keagamaan tersebut telah terkontaminasi oleh berbagai kepentingan seperti, politik, ekonomi, dan juga budaya.

Peradaban dunia dibangun oleh bangsa-bangsa yang memiliki keunggulan bukan hanya dalam bidang sain dan teknologi tetapi yang paling utama adalah bangsa yang warga masyarakatnya memiliki karakter jujur, bertanggung jawab, dan peduli pada orang lain dan menjadi warga negara yang baik. Bentuk-bentuk karakter tersebut yang akan menjadikan sebuah bangsa memiliki kekuatan dan dihargai di tengah pergaulan bangsa-bangsa dunia.

Ketika mayoritas karakter masyarakat kuat, positif, tangguh maka peradaban yang tinggi dapat dibangun dengan baik dan sukses. Adapun nilai-nilai Keindonesiaan ialah nilainilai luhur universal dan kosmopolitan bangsa Indonesia. Nilai-nilai Keindonesiaan tentu harus didasarkan pada agama atau budaya hasil dialog panjang dengan agama. Nilai Keindonesiaan mempunyai peranan yang strategis sekaligus sentral dalam membangun persatuan umat. Persatuan ini menumbuhkan kemantapan diri sendiri sebagai bangsa (Madjid, 1998: 90). Oleh karenanya pertumbuhan kemantapan itu berjalan sejajar dengan pertumbuhan nilai-nilai Keindonesiaan itu sendiri. Kemantapan berimplikasi kepada kebebasan dari rasa takut terhadap pluralime Agama maupun rasa cemas kepada arus globalisme atau pengaruh asing. Sehingga kemantapan nilai Keindonesiaan menjadi pangkal adanya fase pertumbuhan lebih lanjut yang lebih penting, yaitu fase keterbukaan, dapat menerima perbedaan, ataupun hidup dalam perdampingan satu sama lainnya atau dalam istilah komterporernya ialah inklusivitas.

Inklusivitas (Madjid, 1998: 81) dalam kehidupan beragama adalah salah satu aspek yang paling penting dalam masyarakat yang paling pluralisme. Untuk itu Nurcholish Madjid mengatakan bahwa "Indonesia adalah salah satu bangsa yang paling pluralis di dunia" (Madjid, 2000: 35-39), atau dengan kata lain bahwa penduduk Indonesia adalah paling beraneka ragam agama dan kulturnya di muka bumi.

Nilai Keindonesiaan bangsa Indonesia sangat beragam, meskipun realitasnya dalam keberagaman tersebut bermayoritas agama Islam. Islam masuk ke Indonesia dengan cara-cara damai. Untuk itu, modal keindonesiaan yang paling berharga ialah persatuan, keutuhan wilayah negara, bahasa kesatuan, kontitusi dan falsafah negara serta sistem pemerintahan yang meliputi seluruh tanah air, dan pembangunan ekonomi secara pragmatis. Selain itu, modal Keindonesiaan yang paling mahal adalah pengalaman bangsa Indonesia menjalani kehidupan kemasyarakatan yang pluralisme.

Pada titik ini umat Islam dipaksa memikirkan kembali tradisi yang dipegangnya berkaitan dengan perubahan yang sedang terjadi. Respons ini kemudian melahirkan gerakan- 
gerakan pembaharuan. Akan tetapi, pembaharuan Islam bukan sekedar reaksi muslim atas perubahan tersebut. Degradasi kehidupan keagamaan masyarakat muslim juga menjadi faktor penting terjadinya gerakan pembaharuan. Banyak tokoh umat yang menyerukan revitalisasi kehidupan keagamaan dan membersihkan praktik-praktik keagamaan dari tradisi-tradisi yang dianggap tidak Islami.

Atas dasar inilah muncul aspek penting mendalami persoalan pluralisme Agama dalam kehidupan bermasyarakat. kajiannya menjadi sangat relevan sekali dalam konteks Indonesia. Pendalaman terhadap isu ini sepertinya terus dilakukan dengan mengambil sudut pandang berlainan, sehingga akan diperoleh analisis dan pemahaman yang beragam pula. Sehingga pada saat ini telah banyak muncul tokoh-tokoh terutama kalangan muda yang menyuburkan tumbuhnya ide pluralisme (Abdullah, 2003: 441).

Dewasa ini timbul kerancuan mendefinisikan pluralitas dan pluralisme agama. Secara sekilas kata pluralis dan pluralisme itu sama, yaitu terbentuk dari kata plural yang secara etimologi berarti banyak, jamak beraneka ragam ((Pena, 2006: 376). Namun ketika kata plural ini sudah terbentuk menjadi sebuah kata pluralitas dan pluralisme maka akan menjadi kata yang sangat berbeda maknanya serta artinya.

Pluralitas adalah suatu keanekaragaman yang ada dalam suatu mayarakat dan mengakui bahwa hal yang lain ada di luar kelompoknya. Sedangkan pluralisme bukan sekedar fakta atau keadaan yang bersifat plural akan tetapi merupakan suatu sikap yang mengakui sekaligus menghargai dan menghormati bahkan mengembangkan dan memperkaya keadaan yang bersifat plural (Ma'arif, 2005: 12).

Abdurrahman Wahid melihat pluralisme agama itu dalam konteks ajaran universalisme dan kosmopolitanisme dalam Islam. Ajaran yang dengan sempurna menampilkan universalisme adalah lima jaminan dasar yang diberikan Islam kepada warga masyarakat, baik secara personal (individu) maupun sebagai kelompok (impersonal). Hal ini terdiri dari: 1) Keselamatan fisik warga masyarakat dari tindakan badani di luar ketentuan hukum; 2) Keselamatan keyakinan agama masing-masing tanpa ada paksaan untuk berpindah agama; 3) Keselamatan keluarga dan keturunan; 4) Keselamatan harta benda dan milik pribadi di luar prosedur hukum; dan 5) Keselamatan profesi (Borton, 1997: 66).

Dari kelima jaminan dasar tersebut, secara keseluruhan dapat dipahami bahwa menampilkan universalitas pandangan hidup yang utuh dan bulat. Akan tetapi harus di dukung oleh peradaban Islam. Dalam konteks kehidupan yang pluralisme Agama, pandangan Abdurrahman Wahid ini didukung oleh Kuntowijoyo yang menyatakan bahwa hal tersebut terdiri dari beberapa hal yaitu:

Genesis Pemikiran. Menyatakan bahwa sejarah pemikiran selalu mulai dari teks. Pada mulanya adalah teks ( dengan ditebalkan oleh Kuntowijoyo sendiri). Karenanya sejarah pemikiran tidak membatasi diri hanya pada pemikiran perorangan, dan pemikiran teoritis sebagaimana lazimnya sejarah intelektual, tetapi juga pemikiran praktis dari sosiologis pengetahuan. Hal inilah membuktikan bahwa sejarah pemikiran lebih luas dalam aspek keilmuaannya.

Konsitensi Pemikiran. Prinsip aturan utama dalam roses kognitif dan perubahan sikap yang dapat dihasilakan dari informasi yang dapat mengacaukan kesinambungan ini. Walaupun kosa kata dan konsep dari teori itu berbeda, asumsi dasar dari konsitensi adalah 

menghadirkan mereka semua dalam bahasa. Manusia mencari homeostatis atau keseimbangan dan sistem kognitif adalah sebuah alat utama yang dapat digunakan untuk mencapai keseimbangan dalam konsitensi pemikiran dalam pengkajian sebuah penelitian (Kuntowijoyo, 2004: 10).

Evolusi Pemikiran. Merupakan sebuah perkembangan atau perubahan yang bersifat perkembangan sosial, eokonomi, politik dan agama. Hal tersebut tanpa ada paksaan dari waktu ke waktu secara perlahan dan dalam jangka waktu yang lama mengalami perubahan atau pembaharuan terutama mengenai dalam sebauh pemikran.

Sistematika Pemikiran. Sebuah cara untuk memahami sistem yang kompleks dengan menganalisis bagian-bagian sistem tersebut kemudian mengetahui pola hubungan yang terdapat di dalam setiap unsur atau elemen penyusun sistem tersebut. Pada dasarnya berpikir sistematik mengkombinasikan dua kemampuan berpikir pada diri manusia yaitu berpikir analisis dan sintesis kedua inilah yang menjadikan pola pemikiran seseorang lebih terarah dan tersusun.

Penelitian ini yaitu penelitian kepustakaan (library research). Penelitian kepustakaan merupakan telaah yang dilaksanakan untuk memecahkan suatu masalah, yang pada dasarnya bertumpu pada penelaahan kritis dan mendalam terhadap bahan-bahan pustaka yang relevan. Karena penelitian ini seluruhnya berdasar atas kajian pustaka atau literer, maka penelitian ini secara khusus bertujuan untuk mengumpulkan data atau informasi dengan bantuan bermacammacam material yang terdapat dalam ruamg perpustakaan, majalah sejarah serta kisah-kisah (Mardalis, 1995: 28).

Jenis data yang digunakan dalam penelitian ini adalah kualitatif yaitu, upaya memahami masalah dengan memperhatikan bagaimana pluralisme Agama dalam konteks keindonesiaan menurut Nurcholish Madjid yang tertuang melalui karya-karyanya. Sumber data diperoleh dari sumber primer dan sekunder. Beberapa sumber primer adalah hasil-hasil karya tulis Nurcohlish Madjid yaitu, Islam Agama peradaban Membangun Makna dan Relevansi Doktrin Islam dalam Sjarah, Pintu-Pintu Menuju Tuhan, Masyarakat Religius, Atas Nama pengalaman Beragama dan Berbangsa di Masa Transisi, Islam Universal, Islam Kemodernan dan Keindonesiaan, Khazanah Intelektual islam, Kaki Langit Peradaban islam.

Sumber sekunder adalah penunjang dari data primer bersumber dari karya-karya penulis lain yang pro maupun kontra dengan karya. Sumber data sekunder ini bisa bersumber dari buku-buku, tesis, jurnal ilmiah, artikel, dan informasi-informasi yang relevan sangat dibutuhkan sebagai data pendukung.

Penelitian ini merupakan bidang penelitian sejarah pemikiran Islam. Pemikiran yang dikaji di sini adalah pemikiran teoritis bidang sosial keagamaan dan terkait dengan pemikiran praktis dari ide-ide yang semula hanya teoritis. Pendekatan yang digunakan adalah pendekatan kajian teks (Kuntowijoyo, 2004: 128-134). Pendekatan historis, mencakup beberapa tahapan, yaitu:

Heuristik (proses pencarian sumber). Heuristik berasal dari bahasa Yunani yaitu heurishen, artinya memperoleh. Heuristik adalah suatu teknik, suatu seni, dan bukan suatu ilmu. Merupakan suatu keterampilan dalam menemukan, menangani dan memperinci bibiografi, atau mengklarifikasikan dan merawat catatan-catatan (Dudung, 1999: 55) terdahulu itu. Pada tahap ini, penulis mengumpulkan sumber-sumber sejarah dalam usaha 
memperoleh data-data mengenai subjek yang terkait secara langsung (Kuntowijoyo, 2003: 50) mengenai pemikiran Nurcholis Madjid dalam membangun peradaban di Indonesia (studi kritis terhadap implementasi ajaran Islam).

Verifikasi (kritik sumber). Setelah sumber sejarah dalam berbagai katagorinya itu terkumpul, tahap selanjutnya yaitu verifikasi atau kritik sumber untuk memperoleh keabsahan sumber. Dalam hal ini kritik sumber terbagi menjadi dua yaitu kritik ekstern dan kritik intern. Kritik ekstern adalah keabsahan tentang keaslian sumber (otentisitas) (Meloeng, 2001: 59). Peneliti melakukan pengujian atas asli atau tidaknya sumber berarti bagian ini menyelesaikan segi-segi fisik dari sumber yang ditemukan atau setidaknya dapat diuji berdasarkan sebuah pertanyaan-pertanyaan seperti kapan sumber itu dibuat, dan siapa yang membuat. Sedangkan kritik intern adalah menguji sumber tentang kesahihan sumber (kredibilitas) (Meloeng, 2001: 59). Pada kritik intern ini pertanyaan pokok untuk menetapkan kredibilitas ialah pada "nilai bukti apakah yang ada di dalam sumber ?". Kesaksian dalam sejarah merupakan faktor paling menentukan sahih dan tidaknya bukti atau fakta sejarah.

Interpretasi (analisis dan sistem data). dalam interpretasi ini dilakukan dua macam cara, yaitu analisis (menguraikan), dan sintesis (menyatukan) data. dalam langkah ini, peneliti melakukan analisis dan mensintesiskan data yang diperoleh dari sumber tersebut dengan menggunakan pendekatan sejarah sosial intelektual dan sosilogis serta politikologis.

Historiografi adalah langkah terakhir dalam penulisan sejarah. Hal ini merupakan cara penulisan, pemaparan, atau pelaporan hasil penelitian sejarah yang telah dilakukan. Penelitian ini, pada hakekatnya mendasarkan diri pada semua unsur di atas, namun penekanan utama adalah pada perkembangan dan perubahan pemikiran NM. Penetapan fokus ini karena pada pembahasannya juga akan dikaji kondisi sosial masyarakat, yang mengalami pengaruh dari pemikiran NM. Pemikiran NM diasumsikan mengalami pengaruh dari kondisi sistem sosial politik Indonesia. Karena itu memungkinkan terjadinya perubahan-perubahan.

Untuk memperoleh data yang dibutuhkan dalam penelitian ini, maka metode yang digunakan adalah metode dokumentasi dan penelaahan pustaka. Karya-karya tulis yang sudah didapatkan akan dilakukan penelaahan, untuk mengambil data berupa pemikiran seorang tokoh dilakukan tiga tahapan kerja yaitu Inventarisasi, Evaluasi, dan Sintesis. Pada tahap Inventarisasi dilakukan penghimpunan sumber-sumber data baik sumber primer maupun sekunder. Sumber-sumber data tersebut diseleksi, dibaca, dicatat, dan dikategorisasi (Sardra, 2005: 8). Pada tahap Evaluasi kritis dilakukan analisis baik berupa pembandingan maupun analisis dengan melihat kekuatan serta kelemahan dari data yang dimiliki. Pada tahap Sintesis dilakukan pemilihan terhadap unsur-unsur yang memperkaya penelitian, disusun secara sistematis untuk menjawab permasalahan penelitian ini.

Sesuai karakteristik penelitian kualitatif dan pendekatan sejarah intelektual, analisis data dilakukan selama penelitian ini berlangsung. Metode berpikir menggunakan metode induksi. Penelitian berawal dari isu-isu khusus dalam pemikiran pluralisme beragama Nurcholish Madjid serta kejadian-kejadian khusus di masyarakat, mendalaminya, menganalisis, membandingkan dengan pendapat pihak lain. Hasilnya nanti akan memunculkan sebuah proposisi mengenai pluralisme beragama menurut NM dalam konteks Keindonesiaan. 
Dalam menganalisa data, peneliti tetap berpegang pada ketentuan dasar pendekatan sejarah yaitu bersifat diakroni. Diakronis ialah analisis data memanjang menurut urutan waktu, yaitu pluralisme beragama menurut Nurcholish Madjid dalam konteks Keindonesiaan. Hal ini dilakukan agar tidak terjadi tumpang tindih dengan ilmu sosial lain yang bersifat singronis . analisis menggunakan pendekatan sosiologi agama tetap diperlukan, yaitu untuk melihat posisi pemikiran pluralisme beragama di masyarakat. Tetapi sosiologi hanya bersifat ilmu bantu dalam mendalami permasalahan penelitian ini.

Ketajaman analisis akan difokuskan melalui penggunaan analisis wacana kritis (Nata, 2004: 378-380). Penggunaan lima aspek yang dikaji dalam penelitian ini yaitu: 1) Struktur Tematik, pada srtuktur ini akan dijelaskan tema umum yang ingin dikembangkan dalam pemikiran pemikiran pluralisme beragama Nurcholish Madjid. Alasan-alasan pemilihan tema dan latar belakang munculnya pemikiran Nurcholish Madjid akan terlihat dalam struktur ini; 2) Struktur Skematik, dalam bagian ini akan dicermati bagaimana Nurcholish Madjid merangkai pluralisme, mengemasnya dalam bentuk buku serta pemilihan kata-kata. Bagian ini juga menjelaskan bagaimana sebuah kontruksi tentang Nurcholish Madjid sebagai narasumber utama dan guru besar; 3) Srtuktur Semantik, bagian ini akan melihat bagaimana makna yang ingin ditekankan Nurcholish Madjid.

Hal ini akan terlihat dari elemen latar, maksud, dan pra anggapan masyarakat tentang Nurcholish Madjid; 4) Struktur Sintaksis, lewat sruktur ini akan terlihat bagaiman strategi wacana yang dilakukan oleh Nurcholish Madjid, terutama berkaitan dengan bentuk kalimat, koherensi yang dibuat, dan kata ganti yang digunakan. Pada bagian ini juga akan dibahas tentang pilihan kata, istilah, dan pemakain bahasa populer oleh Nurcholish Madjid; dan 5) Struktur Retorik, pada bagina ini ditekankan pada bagaimana NM menampilkan karyanya sebagai sebuah produk yang akan di sebar luaskan.

\section{Mendasari Kemunculan Pemikiran Pluralisme Agama Nurcholis Madjid}

Setiap bangsa yang mempunyai etos atau suasana kejiwaan yang menjadi karakteristik utama suatu bangsa. Etos itu kemudian dinyatakan dalam ideologi dan seterusnya. Perwujudannya dalam bentuk perumusan formal yang sistematik menghasilkan ideologi, khususnya di zaman modern ini. Berkenaan dengan bangsa Indonesia, Pancasila dapat dipandang sebagai perwujudan etos nasional bangsa Indonesia dalam bentuk perumasan formal itu, sehingga sudah sangat lazim dan semestinya bahwa Pancasila disebut sebagai ideologi nasional.

Tetapi Pancasila adalah sebuah ideologi modern. Hal itu tidak saja karena ia diwujudkan dalam zaman modern, tapi juga lebih-lebih lagi karena ia ditampilkan oleh seorang atau kelompok orang dengan wawasan modern, yaitu para bapak pendiri Republik Indonesia, dan dimaksudkan untuk memberi landasan filosofis bangsa (common philosophical ground) (Madjid, 1995: 568) sebuah masyarakat plural yang modern, yaitu masyarakat Indonesia.

Sebagai produk pikiran modern, Pancasila adalah sebuah ideologi yang dinamis, tidak statis, dan memang harus dipandang demikian. Watak dinamis Pancasila itu membuatnya sebagai ideologi terbuka. Presiden Soeharto pernah menegaskan sifat Pancasila sebagai ideologi terbuka itu pada beberapa kesempatan, secara lain pada Kongres dan Seminar 
Nasional Himpunan Indonesia untuk Pengembangan Ilmu-Ilmu Sosial (HIPIS) di Ujungpadang, 15 Desember 1986 (Rakhmat, 2008: 33).

Dalam hal perumusan formalnya, Pancasila tidak perlu lagi dipersoalkan. Demikian pula kedudukan kontitusionalnya sebagai dasar kehidupan bernegara dan bermasyarakat dalam pluralitas Indonesia, juga merupakan hal yang final. Manun dari segi pengembangan prinsip-prinsipnya sehingga menjadi aktual dan relevan bagi masyarakat yang senantiasa tumbuh dan berkembang, Pancasila tidak bisa lain kecuali mesti dipahami dan dipandang sebagai ideologi terbuka yang dinamis. Oleh karena itu tidak mungkin ia dibiarkan mendapat tafsiran sekali jadi untuk selama-lamanya (once forall).

Kemestian logis akibat deretan itu adalah bahwa masyarakat dengan keanekaragaman harus diberi kebebasan mengambil bagian aktif dalam usaha-usaha menjabarkan nilai-nilai ideologi nasional itu dan mengaktualkannya dalam kehidupan masyarakat. Setiap usaha menghalanginya akan menjadi sumber malapetaka, tidak saja bagi negara dan masyarakat Indonesia sebagai masyarakat majemuk, tetapi juga ideologi nasional itu sendiri sebagai titik tolak pengembangan pola hidup bersama.

Sudah menjadi bagaain dari retorika di negara Indonesia bahwa Islam adalah agama mayoritas. Retorika itu mulai menyebutkan angka 90 persentasi yang menunjukkan kaum muslim dari seluruh penduduk Indonesia, tanpa dipermasalahkan dari mana asal-usul angka itu selain perkiraan dan kesan. Karena itu kenyataan efek retorika itu maka ketika sensus menunjukkan angka kaum muslim Indonesia kurang (sedikit) dari 90 persen, timbulkah berbagai tafsiran terhadap kehidupan keagamaan masyarakat Indonesia, baik berdasarkan fakta maupun fiksi (Kuntowijoyo, 1991: 188).

Islam memang merupakan agama bagaian besar bangsa Indonesia, apapun makna penganutan mereka terhadap agama itu dan betapapun beranekanya tingkat intensitas penganutan itu dari kelompok ke kelompok dan dari daerah ke daerah. Namun kenyataan sederhana ini saja kiranya sudah cukup memberi alasan keabsahan bagai pembicaraan tentang Islam di Indonesia dan perannya dalam subtansiasi ideologi nasional, tanpa eksklusifisme, dan tidak dalam semangat kesewenangan suatu kelompok besar.

Kehadiran Islam di Nusantara mendorong terjadinya perubahan pola kekuasaan dan melahirkan kesatuan-kesatuan politik Islam dalam bentuk kesultanan-kesultanan. Agama Islam juga membawa berbagai pandangan-pandangan baru yang revolusioner untuk masa itu. Dapat disebutkan dua hal yang amat penting disini. Pertama, sifat Islam sebagai agama egaliter radikal, yang antara lain berakibat kepada penyudahan sistem kasata dalam masyarakat Hindu Nusantara dan penghentian praktek sati. Kedua, agama Islam dengan kesadaran hukumnya yang sangat kuat (kesadaran syari'at dalam makna sekundernya) telah melengkapi penduduk Nusantara, khususnya para pedagang, dengan sistem hukum yang berjangkauan internasional, yang mampu mendukung kegiatan pedagang dalam konteks ekonomi global yang saat itu sedang berada dalam kekuasaan Islam.

Sudah tentu semua kenyataan itu, ditambah dengan banyak kenyataan lain yang tidak mungkin dijabarkan seluruhnya, mempunyai akibat-akibat yang cukup jauh. Salah satunya bahwa sementara Indonesia merupakan kesatuan bangsa muslim terbesar di muka bumi, namun kontribusi kultural dan, lebih-lebih lagi, intelektualnya sangat jauh dibawah proposinya. Dalam bidang intelektual itu Indonesia boleh dikatakan sebagai konsumen untuk 
produk-produk anak benua ke Barat. Ini dengan mudah dapat dilihat dengan kuantitas komparatif kepuskakaan ilmah Islam di Indonesia dan di negara-negara lain.

Berdasarkan hal ini, maka kiranya cukup beralasan suatu pandangan bahwa Islam di Indonesia sesungguhnya masih dalam tahap perkembangan dan pembentukannya, dan masih menyiapkan masa depannya secara sangat menentukan. Sesungguhnya pula bahwa umat Islam Indonesia sekarang ini betul-betul baru pada tahap permulaan mengecap hasil perjuangan mereka sendiri selama berabad-abad melawan dan menghalau penjajah. Telah dikemukakan di atas fungsi Islam di Nusantara sebagai kelengkapan ideologis menghadapi penjarah yang datang dari Barat. Tradisi dan sejarah panjang semangat perlawanan terhadap penjajah barat itu secara alami membuat kaum muslim sebagai yang paling berkepentingan terhadap kemerdekaan.

Telah dikemukakan bahwa ideologi nasional Pancasila, adalah final kebenaran dengan fungsinya sebagai dasar kehidupan bernegara dan bermasyarakat dalam konteks kemajemukan Indonesia. Kefinalan itu juga berkenaan dengan perumusan atau pengkalimatan formalnya sebagai mana tercantum dalam Pembukaan UUD 1945.

Dapat diketahui bahwa proses menuju kepada kefinalan itu telah sempat menimbulkan polemik dan kontroversi yang tajam dalam masyarakat. Kini dengan lega hati masyarakat Indonesia menyatakan bahwa banyak sekali dari kekuatiran yang ada di balik polemik dan kontroversi itu ternyata tidak ada. Bahkan terhadap tanda-tanda tentang adanya perkembangan yang lebih positif dari pada yang diduga semula.

Tetapi untuk memperoleh agak lebih jauh dalam garis argumen ini dirasa perlu disingging beberapa hal. Dalam kekhawatiran para pendiri bangsa atas enggan menerima kefinalan Pancasila yang timbul dari dugaan bahwa Pancasila akan diarahkan kepada posisi sebagai akutivalent bagi suatu agama. Atau lebih sederhananya, Pancasila akan "diagamakan", menggantikan suatu agama atau agama-agama yang ada. Secara common sense memang segera menampak oleh kebanyakan pengamat kemustahilan gagasan serupa itu. Dalam kitab suci cita-cita dalam ungkapan jargon modern sebagai mewujudkan keadilan sosial (Madjid, 1995: 125). Tetapi kenyataan menunjukkan bahwa dugaan yang mustahil itu telah pernah melatar belakangi polemik dan kontroversi yang seru. Dan sebagaimana telah dikatakan, ternyata kekhawatiran itu sama sekali tidak terbukti, malah justru banyak timbul gejala yang lebih positif.

Pancasila sebagai ideologi terbuka, sesuai dengan rancangannya untuk landasan kehidupan sosil politik Indonesia yang plural dan modern. Suatu fase kemantapan nasional amat penting telah terjadi di negara Indonesia berkenaan dengan kefinalan Pancasila, yaitu diterimanya ideologi itu sebagai satu-satunya asas bagi kehidupan bermasyarakat dan bernegara dalam konteks pluralisme dan keterbukaan. "hal itu berarti bahwa gambaran masyarakat hari esok yang berlandaskan Pancasila masi perlu kita jabarkan dan kita kembangkan lebih jauh" (Madjid, 1997: 78).

Kutipan itu memberikan penjelasan singkat tentang apa makna pandangan bahwa Pancasila adalah sebuah ideologi terbuka. Yaitu bahwa ia tidak memberikan penafsiran secara detail dan nyata "sekali untuk selamanya," tanpa bisa diubah-ubah. Jadi ia tidak mengizinkan adanya indokrinasi. Melainkan Pancasila sebagai nilai-nilai dasar harus senantiasa disahakan merinci tuntutan-tuntutan pokoknya dengan menghadapkan setiap konsep dan gagasan 
tentang makna idealnya kepada kenyataan-kenyataan masyarakat Indonesia yang senantiasa berubah dan berkembang secara dinamis.

Tanpa harus menyebutkan perkembangan sejarah secara terperinci, cukuplah kiranya disebutkan disini bahwa para pendiri bangsa ini pada tahun 1945 akhirnya membuat kompromi dengan menetapkan Pancasila sebagai dasar negara. sila pertama, Ketuhanan Yang maha Esa, menunjukkan bahwa negara Indonesia bukan negara sekuler sekaligus bukan negara Islam.

Dalam kondisi yang demikian, lebih-lebih di era Reformasi yang membuka lebar kebebasan berpendapat dan berserikat, dalam gagasan Mengindonesiakan Islam, integrasi paham Keislaman dan kebangsaan. Masalah hubungan agama, warganegara,dan bangsa adalah masalah ijitihad yang sangat erat hubungannya dengan konteks sosial politik yang dipahami umat itu sendiri.

Islam dan kemajemukan Indonesia siapa pun yang mencoba mengenali Indonesia, tanpa perlu banyak berpikir, dia akan segera sadar betapa beragamnya dan majemuknya masyarakat Indonesia. Ada sekian ratus sub suku dengan bahasa-bahasa atau dialek yang khas. Ada baanyak agama dan kepercayaan, ada beraneka warna adat-isdiadat, dan berbagai organisasi keagamaan baik dalam Islam itu sendiri atau agama-agama lainnya. Gagasan perbedaan dan kemajemukan dalam bingkai persatuan memberikan perhatian serius pada masalah kemajemukan ini sebagai fakata yang tidak dapat ditolak. Ole karena itu, sikap kita terhadap kemajemukan itu harus positif.

Dengan kata lain, sikap yang dikembangkan adalah upaya untuk menghormati berbagai perbedaan yang ada sambil mencoba mengelolanya secara damai dan berkeadilan. Sikap negatif yang mencoba menaklukkan kemajemukan menjadi keseragaman atau berusaha mengsingkan diri dari berinteraksi dengan kemajemukan adalah sikap yang tidak realitis dan merugikan. Kadang-kadang pernah terjadi sikap saling menyalakan, bahkan saling mengkafirkan, tetapi ada pula usaha-usaha yang cukup berhasil dalam membina pesaudaraan diantara agama-agama ataupun aliran-aliran yang berbeda itu.

Bagi Nurcholish Madjid, yang terkahir inilah yang sesuai dengan semangat dasar. Perbedaan antar agam juga menjadi perhatian Nurcholish Madjid. Baginya agama sebagai kebenaran yang bersifat universal karena berasal dari Yang Maha Besar. Islam dalam makna generiknya, yakni tumbuh dan pasrah pada Tuhan, merupakan kebenaran universal tersebut yang ada pada semua agama yang benar, Keesaan Tuhan dan kebenaran agama berimplikasi pada kesatuan umat.

Pergulatan modernitas dalam dunia Islam melahirkan upaya-upaya pembharuan terhadap tradisi yang ada. Meskipun gerakan pembaharu Islam tidak dapat disebut modernisme Islam karena konteknya berbeda. Gerakan pembaharu yang dilakukan di Indonesia yang merujuk pada modernisme, untuk mewujudkan peradaban dunia Islam di Indonesia dalam menjawab tantangan global. Salah satunya adalah Nurcholish Madjid, yang menggabungkan modernisasi dan rasionalisasi. Hal ini berarti suatau proses perombakan pola berpikir dan tata kerja baru yang tidak rasional dan menggantikan dengan proses berpikir dan taat kerja baru yang lebih rasional.

Dengan demikian, ditegaskan oleh Nurcholish Maddjid (Abdullah, 2010: 5) bahwa "yang disebut modern adalah jika ia bersifat rasional, ilmiah, dan bersesuaian dengan hukum- 
hukum yang berlaku dalam alam. Hal tersebut disebabkan modernisasi suatu keharusan karena modernisasi juga adalah kebenaran, dan moderenisasi sebagai usaha atau proses mencapai kebenaran".

Berdirinya Negara Indonesia yang dilandasi Pancasila, sebagaimana dimaksud oleh founding fathers, mempungsikan agama-agama aktif memperjuangkan dan menegakkan nilainilai kemerdekaan, kerakyatan, keadilan, dan kesatuan. Identitas masing-masing agama tidak dilenyapkan, tetapi agama-agama diletakkan dalam kerangka yang lebih luas, yaitu hal ini mengandung arti bahwa agama-agama perlu mengadakan kontekstualisasi ajaran-ajaranya di Indonesia. Dengan perkataan lain, ideologi kebangsaan menjadi semacam konteks yang tidak dapat di tiadakan oleh agama-agama.

\section{Islam Inklusif}

Dengan tegas bahwa Islam adalah agama yang terbuka. Umat Islam harus tampil dengan percaya diri, bijaksana dan arif dalam menghadapi kemajemukan. Sikap inklusif sangat dianjurkan dalam menjalani hidup di tengah pluralisme agama. Sikap inklusif tersebut tentunya meniscayakan adanya paham pluralisme dan bisa juga sebaliknya, bahwa pluralisme menuntut adanya sikap inklusivisme. Karena pluralisme merupakan realitas yang niscaya, dalam bentuk apa dan dimanapun kita berada, maka sikap inklusivisme itupun menjadi suatu keniscayaan. Disinilah kemudian muncul interaksi sosial anatarkeyakinan dan ideologi, yaitu apa yang biasa disebut dialog (Madjid, 1998: 98-99).

Secara ekspresif, Nurcholis Madjid mengemukakan bahwa pluralisme agama secara substansial adalah paham inklusif yang berarti bahwa seluruh kebenaran ajaran agama lain ada juga dalam agama kita. Nurcholis menunjukkan bahwa tidak ada kebenaran mutlak dan adanya pengakuan terhadap kebenaran agama lain. Pengakuan ini tidak berarti menafikan terhadap kebenaran pemahaman dirinya sendiri sebagai agama yang dipeluk. Oleh karena itu, pluralisme agama hanya ada kalau ada sikap-sikap keterbukaan, saling menghargai dan toleransi. Ajaran ini menegaskan pengertian dasar bahwa semua agama diberi kebebasan untuk hidup (Ridwan, 2002: 12).

Dalam menggagas pluralisme agama ini, Nurcholis mengaitkan dengan tujuan orang beragama untuk bersikap lapang dan terbuka. Menurutnya, sebaik-baik agama disisi Allah adalah al-hanifiyyah al-samhah yaitu mencari kebanaran secara terbuka yang membawa sikap toleran, terbuka, tidak sempit, tidak fanatik dan tidak membelenggu jiwa. Dalam ide pluralisme agama yang dibawanya, Nurcholis Madjid menunjukkan bahwa Islam adalah sebuah ajaran yang mencari dan berpegang pada kebenaran secara lapang dan all inclusive dengan memberi tempat pada pengakuan semua agama, semua kitab suci dan semua Nabi. Semangat inilah yang menunjukkan bahwa pluralisme agama dalam gagasan Nurcholis madjid ingin melebur keberbedaan agama dalam keterbukaan, saling menghormati, saling toleransi, bekerja sama bahu-membahu dalam memperjuangkan keadilan dan saling menghormati harkat kemanusiaan bersama-sama. Dalam pemikirannya, Nurcholis sangat mengedepankan optimisme yang tinggi terhadap berhasilnya pencapaian "titik temu" dari berbagai agama.

Hal tersebut justru menjadi kelemahan karena semangatnya yang didasarkan bahwa umat Islam adalah mayoritas seakan-akan mengesampingkan agama lain, dalam arti jika 
bagian terbesar tadi adalah agama selain Islam maka tidak akan terjadi titik temu dan keterbukaan terhadap agama lain Pendapat Nurcholis tentang Manusia akan senantiasa berselisih (dan mereka yang tidak berselisih adalah yang mendapat rahmat Tuhan) karena "keputusan" atau "takdir" Tuhan untuk makhluknya yang akan tetap berbeda-beda sepajang masa dan bersifat perennial, juga mengisyaratkan bahwa jika seseorang ada dalam sebuah agama, konflik dengan agama lain akan dianggap sebagai tindakan kebenaran melawan kelaliman. Sedangkan jika seseorang berada dalam agama lain, maka ia akan dianggap sebaliknya .

Dalam konteks ini, menunjukkan bahwa sikap selalu berselisih adalah sebuah apologi karena selamanya masing-masing pemeluk agama akan membela mati-matian agama mereka. Tentang sikap keterbukaan, harus mengedepankan kerendahan hati untuk tidak selalu merasa benar, kemudian bersedia untuk mendengarkan pendapat orang lain untuk diambil dan diikuti mana yang terbaik. Tapi hal ini justru bertentangan dengan semangat keagamaan umat Islam dalam menyebarkan ajaran yang paling sempurna, tidak ada keraguan didalamnya dan rahmatan lil alamin.

Visi keberagamaan yang inklusif yang dilakukan bukan hanya sekedar pandangan yang bersedia menerima perbedaan dalam kehidupan beragama. Lebih dari itu, Islam yang terbuka adalah ciri penting yang menunjukkan bahwa ajaran agama kita sangat menghargai prinsip-prinsip beragama yang dipegang oleh umat beragama lain namun tetap berpegang teguh pada ajaran kita sendiri. Lebih jauh Nurcholis memberikan pemahaman betapa Islam adalah agama yang terbuka adalah dengan menafsirkan ayat Al-quran surat Ali - Imran : 9, yang berbunyi : Artinya: "Ya Tuhan kami, Sesungguhnya Engkau mengumpulkan manusia untuk (menerima pembalasan pada) hari yang tak ada keraguan padanya". Sesungguhnya Allah tidak menyalahi janji.( Qs. Ali - Imran : 9)

Nurcholis menerjemahkan ayat tersebut bersandar pada tafsir The Holy Qur'an karangan Muhammad Asad yang menurutnya kitab tafsir tersebut dikerjakan dengan banyak menggunakan referensi tafsir-tafsir lama. Yang jika diterjemahkan dalam Bahasa Indonesia, ayat tersebut berarti : Sesungguhnya agama di sisi Allah ialah sikap pasrah kepada-Nya.

Kata Islam di sini juga diterjemahkan, bukan sebagai agama, tapi Islam sebagai "pasrah kepada Tuhan". Itulah sebabnya seluruh agama-agama Nabi terdahulu disebut Islam, karena semuanya mengajarkan sikap tunduk dan patuh kepada Tuhan. Pendapat Nurcholis tentang semua agama adalah Islam, atau secara generik beliau mengartikan sebagai "sikap pasrah kepada kebenaran (Tuhan)", berarti bahwa Islam adalah agama yang paling unggul dan paling sempurna dan tidak ada keraguan didalamnya. Kesempurnaan Islam adalah karena agama ini bersifat ngemong, mengayomi semua agama yang ada. Dan dalam semua agama mengandung unsur tauhid. Persoalannya adalah bagaimana penganutnya membawa tauhid yang benar pada agama mereka sendiri. Karena keseragaman yang mutlak pada semua Mushhaf atau penerbitan Al-qur'an itu, maka kaum muslimin juga memiliki ketentraman batin yang tinggi terhadap kitab sucinya (Madjid, 1995: 3).

Nabi pernah berkata bahwa sebaik-baik agama di sisi Allah adalah al-hanifiyat alsamhah. Yakni yang bersemangat mencari kebenaran yang lapang, toleran, tanpa kefanatikan dan tidak membelenggu jiwa. Tekanan pengertian itu pada suatu agama terbuka, atau cara penganutan agama yang toleran (Madjid, 1998: 13). Sehingga dialog, sebagai konsekuensi 
dari interaksi sosial masyarakat beragama adalah salah satu cara yang harus ditempuh jika mereka hendak menciptakan hubungan yang harmonis antarumat beragama.

Dialog intra-agama bertujuan kepada pemahaman. Bukan untuk mengalahkan yang lain atau untuk mencapai kesepakatan penuh atau pada suatu agama universal. Cita-citanya adalah komunikasi untuk menjembatani jurang ketidaktahuan dan kesalahpahaman timbal balik antar budaya dunia yang berbeda-beda, memberi ruang bicara dan mengungkapkan pendapatdalam bahasa mereka sendiri (Panikkar, 1994: 33-34).

Pemahaman terhadap eksistensi keberagaman yang melahirkan sikap terbuka dan menerima dialog akan berimplikasi terhadap perilaku sosial para penganut ajaran agama. Kemudian aspek berikutnya yang akan muncul dari sikap-sikap tersebut adalah toleransi. Kita, umat Islam harus berlapang dada dengan adanya berbagai pandangan atau pendapat yang tidak sejalan dengan faham keagamaan kita, baik yang seagama ataupun yang berasal dari luar agama kita. Semuanya adalah hukum ketetapan Allah yang tidak perlu sampai menimbulkan perpecahan.

Dalam pandangan Islam, pijakan untuk membangun toleransi adalah berdasarkan tiga karakter Islam, yaitu : 1). Tidak ada agama selain Islam yang sangat menekankan persamaan derajat; 2). Islam itu rasional dan sederhana (simplicity); 3). Islam adalah kemajemukan. Kedepannya, dialog dan kerjasama agama-agama urgen dilakukan. Tidak saja dialog dan kerjasama mengenai hal-hal yang berkaitan dengan aksi-aksi sosial, tetapi bahkan soal pendalaman makna dan pesan ajaranajaran agama tersebut. Dialog dan kerjasama ini diharapkan memantapkan keimanan umat beragama terhadap agamanya masing-masing sekaligus dapat mengembangkan sikap positif terhadap umat lain yang berbeda agama dengan dirinya (Lubis, 2005: 97-98). Sikap pasrah dan ikhlas menerima eksistensi pluralisme agama memiliki pesan yang bisa membuka kesadaran keberagamaan yang lapang, toleran, egaliter, dan semuanya itu adalah bingkai dari pemikiran inklusifisme agama (Sukidi, 2001: 6).

\section{Islam Dialogis}

Konsep dakwah dialogis dan humanis sangat dianjurkan mengingat keberadaan masyarakat yang heterogen dan umat Islam sendiri akan menjadi umat yang secara mendasar mempunyai ajaran mengenai kepatuhan, kepasrahan dan perdamaian. Dalam komunitasnya, umat Islam mampu membangun kesepahaman dalam masyarakat, tepo seliro, serta sikap saling menghargai (Madjid, 2004: 178) .

Kehadiran Islam sebagai agama yang dibawa oleh Nabi Muhammad sebenarnya tidak menegasikan agama-agama samawi lainnya, karena secara kebahasaan, Islam sebenarnya mempunyai perhatian yang sangat mendasar terhadap perdamaian, keadilan dan kemaslahatan. Sejatinya setiap muslim dapat menebarkan kedamaian dalam kehidupan sosial yang pluralistik, karena kemasalahatan bukan hanya milik personal, tetapi juga milik sosial.

Dialog agama dinilai penting untuk menyingkap ketertutupan yang selama ini menyelubungi hubungan antar agama.

Dialog adalah satu bentuk aktivitas yang menyerap ide keterbukaan. Sebab dialog tidak mungkin dilakukan tanpa adanya sikap terbuka antara masing-masing pihak yang berdialog. Dialog antar iman itu bukan hanya mungkin tapi juga perlu untuk melahirkan pemahaman yang benar terhadap keyakinan beragama (Madjid, 2004: 202). Setiap pemeluk 
agama harus menyadari kenyataan tentang pluralisme. Sebab hanya dengan cara itu hubungan dialogis bisa dibangun.

Apakah mungkin dialog antar umat beragama bisa dilaksanakan? Demikian pertanyaan dialektis Nurcholish Madjid yang sering muncul dalam setiap pertemuan antarumat beragama dalam mengupas dialektika antara mewujudkan kemungkinan untuk bersikap pluralis dalam menjalin hubungan beragama, dengan kemungkinan kegagalan mewujudkannya karena masih banyak umat Islam yang menolak dialog, yakni mereka yang menuntut adanya kebenaran mutlak dan berpendapat bahwa agama secara total berbeda bahkan bertentangan satu sama lain (Madjid, 1998: 174) . Nurcholish menegaskan bahwa masalah pluralisme dalam arti apapun bukanlah sesuatu yang unik dan diherankan, terlebih lagi di jaman modern, sebab secara sosiologis pun realitas kemajemukan selalu ada. Mendasarkan diri pada Al-Quran, Nurcholis mencoba mengkaji masalah klaim kebenaran ini secara lebih mendalam. Tanpa bermaksud mereduksi kebenaran yang diyakini oleh masingmasing agama, Nurcholish melihat kembali unsur-unsur yang telah ada dalam masing-masing agama, terutama agama Islam, yakni toleransi, kebebasan, keterbukaan, kewajaran, keadilan dan kejujuran.

Ide tentang pluralisme, merupakan prinsip dasar dalam Islam, sebuah kenyataan objektif komunitas manusia sejenis hukum Allah dan bahwa hanya Allah yang tahu dan dapat menjelaskan di hari akhir nanti mengapa kita diciptakan berbeda (Zuhriyyah, 2003: 50). Kemajemukan keagamaan ini menandakan pengertian dasar bahwa semua agama diberi kebebasan untuk hidup, dengan resiko yang akan ditanggung oleh para pengikut agama masing-masing, baik secara pribadi maupun kelompok. Sikap ini mengandaikan adanya harapan kepada semua agama yang ada, yakni karena semua agama itu pada mulanya berlandaskan kepada prinsip yang sama yaitu keharusan manusia untuk berserah diri kepada Yang Maha Esa, menyadari dirinya sebagai seorang manusia individual dan manusia universal sekaligus (Madjid, 1992: 184).

Pluralisme agama adalah membangun suatu kehidupan keberagamaan di masa depan dengan lebih menghargai entitas masing-masing ajaran agama serta kompleksitas potensi yang dimiliki oleh masing-masing pemeluknya, dengan tetap menjaga identifikasi agama masing-masing. Ada satu fakta yang tak dapat diingkari, bahwa terminologi pluralisme atau dalam bahasa Arabnya, al ta"addudiyyah, tidaklah dikenal secara populer dan tidak banyak dipakai di kalangan Islam kecuali sejak kurang lebih dua dekade terakhir abad ke 20 yang lalu.

Yaitu ketika terjadi perkembangan penting dalam kebijakan internasional Barat yang memasuki sebuah fase yang dijuluki Muhammad sebagai —imarah" sebagai marhalat alijtiyah (fase pembinasaan). Yakni sebuah perkembangan yang prinsipnya tergurat dan tergambar jelas dalam upaya Barat yang habis-habisan guna menjajakan ideologi modernnya yang dianggap universal, seperti demokrasi, pluralisme, HAM, pasar bebas dan mengekspornya untuk konsumsi luar dalam rangka mencapai berbagai kepentingan yang sangat beragam. Suatu kebijakan yang telah dikemas atas dasar superioritas ras dan kultur Barat, serta peremehan atau penghinaan terhadap segala sesuatu yang bukan Barat, Islam khususnya, dengan berbagai tuduhan yang menyakitkan, seperti toleran, anti demokrasi, fundamentalis, sektarian dan sebagainya. Maka sebagai respons terhadap perkembangan 
politis baru ini, masalah pluralisme mulai mencuat dan menjadi concern kalangan cerdikcendekia Islam, yang pada gilirannya menjadi komoditas paling laku di pasar pemikiran Arab Islam kontemporer (Thoha, 2005: 80-81).

Islam datang dengan prinsip kasih sayang (mahabbah), kebersamaan (ijtima"iyah), persamaan (musawah), keadilan (,,adalah), dan persaudaraan (ukhuwah), serta menghargai perbedaan. Islam hadir untuk menyelamatkan, membela, dan menghidupkan kedamaian. Agama Islam adalah agama yang mendambakan perdamaian. Islam sendiri dari kata empat huruf (rubai) yaitu aslama-yuslmimu-islaman yang berarti mendamaikan dan menyelamatkan. Perdamaian memang impian kemanusiaan, sehingga Nabi menempatkannya pada posisi yang penting dalam ajaran Islam. Seperti yang ditunjukkan oleh persaudaraan kaum Anshar (penduduk Madinah) dan kaum Muhajirin (pendatang dari Makkah). Semangat persaudaraan inilah yang melahirkan kedamaian di setiap hati kaum Muslim, dan berimbas pada rasa perdamaian dalam hubungan sosial termasuk terhadap non-Muslim. Setiap Muslim sejatinya dapat menebarkan kedamaian dalam kehidupan sosial yang pluralistik (Rahman, 2001: 45).

Nurcholis Madjid menekankan tentang pluralisme adalah sebuah sunnatullah yang tidak akan berubah, sehingga tidak mungkin dilawan atau diakhiri. Sesuai dengan Q.S Al Hujurat ayat ke 9 Artinya: "Dan kalau ada dua golongan dari mereka yang beriman itu berperang hendaklah kamu damaikan antara keduanya! Tapi kalau yang satu melanggar perjanjian terhadap yang lain, hendaklah yang melanggar perjanjian itu kamu perangi sampai surut kembali pada perintah Allah. Kalau dia telah surut, damaikanlah antara keduanya menurut keadilan, dan hendaklah kamu berlaku adil; sesungguhnya Allah mencintai orangorang yang berlaku adil.” (Q.S Al Hujurat: 9).

Ber-Islam adalah hidup secara damai dan memahami keragaman. Beragama tidak lagi berperang, tidak lagi membenci dan memusuhi orang lain. Sejauh upaya perdamaian dilakukan, disitulah sebenarnya esensi Islam yang ditegakkan. Spirit perdamaian sejatinya menjadi budaya yang menghiasi kehidupan sehari-hari. Pluralitas keagamaan dalam pandangan para ulama Islam lebih mengupas masalah koeksistensi dan interaksi sosial praktis antar anak manusia yang berafiliasi kepada agama, tradisi dan kultur yang berbeda: yakni masalah yang berhubungan dengan bagaimana mengatur dan mengurus individu-individu dan/atau kelompok-kelompok yang hidup didalam sebuah tatanan masyarakat yang satu, baik yang menyangkut hak maupun kewajiban, untuk menjamin ketentraman dan perdamaian umum.

Jadi, permasalahannya lebih merupakan masalah aplikatif, praktis, administratif, dan historis, daripada masalah keimanan atau teologis, dimana wahyu telah menuntaskan dan menyerahkan semuanya kepada kebebasan dan kemantapan individu untuk memilih agama atau keyakinan sesuai dengan yang mereka yakini (Thoha, 2005: 18), sebagaimana firman Allah SWT dalam QS. Surat Al Baqarah ayat 256. yang artinya: "Tidak ada paksaan untuk (memasuki) agama (Islam); sesungguhnya telah jelas jalan yang benar dar ipada jalan yang sesat.” (QS. Al- Baqarah: 256).

Dalam pandangan masyarakat yang optimis, kemajemukan bukan ancaman, tapi ia merupakan kenyataan yang sekaligus tantangan. Dalam konteks ke-Indonesiaan yang selalu ingin melihat bahwa kemajemukan dalam perspektif Islam sudah menjadi keharusan historis yang niscaya. Karenanya, pemikiran Islam mesti bersikap inklusif dan toleran, tapi sekaligus 
kritis. Nurcholish tampak menggunakan pola pemikiran neo-modernisme dalam keseluruhan gagasan-gagasan pemikiran Islamnya. Pola pemikiran Islam neomodernisme ini.

Pola pemikiran neo-modernisme adalah pengembangan suatu metodologi sistematis yang mampu melakukan panafsiran Islam secara menyeluruh dan selaras dengan kebutuhan kontemporer, sikap tidak mengalah kepada Barat, tetapi juga tidak menafikannya, dan apresiatif disertai sikap kritis untuk mau mengkaji warisan-warisan sejarah keagamaannya sendiri.

\section{Islam Humanis}

Islam adalah merupakan agama kemanusiaan. Dalam pandangan mengenai hubungan Islam dan pluralisme sebenarnya berpijak pada semangat humanitas dan universalitas Islam. Universalitas Islam disini secara teologis bisa diartikan bahwa semua agama yang benar adalah bersifat-Islam (sikap pasrah kepada Tuhan) karena mengajarkan kepasrahan keapada Tuhan dan perdamaian. Dalam perspektif ini menurut Nurcholis, umat Islam sebagai golongan mayoritas harus menjadi golongan yang bisa tampil dengan percaya diri yang tinggi, bersikap sebagai pamong yang bisa ngemong golongangolongan lainnya, bekerja sama dalam kebaikan tanpa membeda-bedakan. Mengutip perkataan Gus Dur, bahwa menjunjung tinggi agama sendiri tidak harus dengan menjatuhkan agama yang lain. Jadi dialog antar agama dapat dipandang sebagai pelaksanaan ajaran agama yang paling asasi, dan kerjasama kemanuasiaan yang menghasilkan berdasarkan keimanan kepada Tuhan Yang Maha Esa dan kebaikan adalah perintah dalam kitab suci (Madjid, 2001: 20).

Al-Qur'an (Q.S. Al-Baqarah: 148), mengakui masyarakat terdiri berbagai macam komunitas yang memiliki orientasi kehidupan sendiri-sendiri. Manusia harus menerima kenyataan keragaman budaya dan agama serta memberikan toleransi kepada masing-masing komunitas dalam menjalankan ibadahnya. Pada dasarnya setiap manusia mempunyai kebebasan untuk meyakini agama yang dipilihnya dan beribadat menurut keyakinan tersebut. Dalam Al-Qur'an banyak ayat yang berbicara tentang penerimaan petunjuk atau agama Allah.

Penerimaan terhadap sebuah keyakinan agama adalah pilihan bebas yang bersifat personal (Riyal, 2005: 68). Secara normatif, dalam Al-Qur'an terdapat beberapa ayat yang isinya mengarah pada nilai-nilai pluralisme. Misalnya ayat 13 dari surat Al-Hujarat : Artinya: "Hai manusia, sesungguhnya kami telah menciptakan kamu sekalian dari laki-laki dan perempuan serta menjadikan kamu berbangsa-bangsa dan bersuku-suka supaya kamu saling mengenal. Sesunguhnya orang yang paling mulia di antar kamu di sisi Allah adalah orang yang paling bertakwa di antara kamu, sesungguhnya Allah Maha Mengetahui lagi Maha Mengenal"(Q.S Al-Hujarat: 13).

Berdasarkan ayat tersebut dapat diketahui bahwa dijadikannya makhluk dengan berbangsa-bangsa dan bersuku-suku adalah dengan harapan mereka dapat berinteraksi secara baik dan positif. Sikap kaum muslim kepada penganut agama lain jelas, sebagaimana ditegaskan dalam Alquran, yaitu berbuat baik kepada mereka dan tidak menjadikan perbedaan agama sebagai alasan untuk tidak menjalani hubungan kerjasama, apalagi mengambil sikap tidak toleran. Dalam ayat lain, yaitu QS. Hud : 118 juga disebutkan bahwa :Artinnya: "Jikalau Tuhanmu menghendaki, tentu Dia menjadikan manusia umat yang satu, tetapi mereka senantiasa berselisih pendapat”. 
Dari ayat ini dapat dipahami bahwa kalau Tuhan mau, dengan sangat mudah akan menciptakan manusia dalam satu group, monolitik dan satu agama, tetapi Allah tidak menghendaki hal-hal tersebut. Allah malah menunjukkan kepada realita, bahwa pada hakikatnya manusia itu berbeda-beda, dan atas dasar inilah orang berbicara pluralisme. Kemajemukan sangat dihargai dalam ajaran Islam, karena Islam adalah agama yang sesuai dengan fitrah kemanusiaan. Salah satu fitrah itu adalah kemajemukan yang hakikatnya bersumber dari ajaran agama.

\section{Kesimpulan}

Pluralisme agama adalah sebuah paham tentang pengakuan keberadaan (bahkan kebenaran, untuk kalangan tertentu) agama-agama lain dalam pandangan Islam yang menganjurkan manusia untuk bersikap dewasa dan positif dalam menghadapi keadaan tersebut, menerima keanekaragaman, toleransi yang memberikan kebebasan dan kesempatan bagi setiap orang menjalani kehidupan menurut keyakinan masing, karena yang dibutuhkan dalam masyarakat majemuk adalah agar setiap manusia berlomba-lomba dalam kebaikan dengan jalan yang sehat dan benar. Pluralisme agama lahir dari fenomena konflik antar agama yang kemudian mengharuskan lahirnya sikap toleransi antara pemeluk agama satu dengan pemeluk agama yang lain. Pluralisme agama dalam Islam didasarkan pada bukti bahwa Islam merupakan agama inklusif yang bersifat terbuka yang mempunyai sikapsikap unik yang berbeda dari sikap-sikap kegaamaan yang lain, yaitu toleransi, kebebasan, keterbukaan, keadilan dan kejujuran.

Ide pluralisme agama Nurcholish Madjid yang beliau katakan sebagai prinsip dasar dalam Islam bermaksud memberikan pengertian kepada umat beragama bahwa kemajemukan keagamaan ini menegaskan pengertian dasar bahwa semua agama diberikan kebebasan untuk hidup dengan resiko yang akan ditanggung oleh para pengikut gama masing masing. Nurcholis juga menerangkan bahwa semua agama pada dasarnya adalah islam dalam arti umum "sikap pasrah kepada Tuhan". Maka tidak mustahil semua umat beragama bisa mendapatkan pertolongan dari Tuhan yang selama ini diklaim hanya milik salah satu agama saja. Nurcholish memberikan ciri-ciri dari inklusivisme Islam yang menjadi dasar pemikirannya tentang pluralisme agama adalah adanya penolakan terhadap ekslusivisme dan abosolutisme yang menyebabkan konflik dan sekaligus menjadi tantangan dakwah Islam dalam kehidupan keberagaman. 


\section{Daftar Pustaka}

Andito, Atas Nama Agama, Bandung, Pustaka Hidayah, 1998.

Anis Malik Thoha, Tren Pluralisme Agama, Gema Insani, Jakarta, 2005.

Azra Azumadi , Esai-Esai Intelektual Muslim dan Pendidikan, Jakarta, Logos Wacana Ilmu, 1999.

Culla, Adi Syuriadi, Rekontruksi Civil Society Wacana dan Aksi Ornop di Indonesia, Jakarta, LP3ES, 2006.

Diputra Oka, Agama dan Budaya Perdamainan Dalam Masyarakat Kristen, Dalam Damai di Dunia Damai Untuk Semua Prespektif Berbagai Agama, Jakarta, Badan Litbang Agama Dan Diklat Keagamaan Departemen Agama R.I, 2004.

Madjid, Nurcholis, Pintu-Pintu Menuju Tuhan, Jakarta : Paramadina, 1994. , Islam Doktrin dan Peradaban; Sebuah Telaah Kritis Masalah

Keimanan, kemanusiaan dan Kemoderenan (cetakan ke II), Jakarta : Penerbit Paramadina, 1992. , Islam Doktrin dan Peradaban; Sebuah Telaah Kritis Masalah

Keimanan, kemanusiaan dan Kemoderenan (cetakan ke III), Jakarta :Paramadina, 1995. , Islam Agama Peradaban (cetakan ke I), Jakarta : Paramadina,

1999. Islam Universal, Yogyakarta : Pustaka Pelajar, 2007. , Islam Kemodernan dan Keindonesiaan, Bandung : Mizan, 1992. , Makalah "Wawasan Al-Qur'an tentang Ahl al-Kitab" pada Munas kerukunan Hidup antar umat beragama di Indonesia 7 juni 1993.

Madjid, Nurcholis Dkk, Umat Beragama Dan Persatuan Bangsa, Jakarta : PT

Penebar Swadaya, 1994.

Masyarakat Religius, Jakarta, Paramadina, 2000.

Mansouf Fakih, Islam Sebagai Alternatif, Pengantar Untuk Eko Prasetyo. Islam Kiri Melawan Kapitalisme Modal Dari Wacana Menuju Gerakan, Yogyakarta, Pustaka Pelajar dan Insist, 2002. 